\title{
PROTEIN SYNTHESIS IN DIFFERENT TISSUES OF MATURE RAINBOW TROUT (SALMO GAIRDNERI R.). INFLUENCE OF TRIPLOIDY
}

\author{
B. Fauconneau, ${ }^{*}$ P. Aguirre and J. M. Blanc \\ Fish Nutrition Research Unit, Station d'Hydrobiologie, I.N.R.A. St Pée sur Nivelle, B.P. 3. 64310 Ascain, \\ France (Telephone: 9928-5002)
}

(Received 24 May 1990)

\begin{abstract}
The composition and protein synthesis rates of the liver, digestive tract, muscle, skin and remains were analysed in mature diploid $(2.1 \mathrm{~kg})$ and triploid $(1.8 \mathrm{~kg}), 3$ year-old rainbow trout reared at $8^{\circ} \mathrm{C}$.

2. The lipid and DNA concentration of the digestive tract were respectively $16-17 \%$ and $30 \%$ higher in the triploids than in the diploids.

3. The DNA and RNA concentration in the other tissues were relatively similar between the diploids and triploids, except in the male gonad.

4. In vivo protein synthesis rates were measured using a single high dose injection of $\mathrm{L}-\left[\mathrm{U}-{ }^{14} \mathrm{C}\right]$-arginine $(0.55 \mathrm{mmol} / \mathrm{kg})$.

5. A small amount of radioactivity was found in the lipid of the whole trout ( $2-3 \%$ of the injected dose)

6. According to their mean Fractional Protein Synthesis Rates (FSR) of protein, tissues were ranked as follows: liver $\left(1.6-44 \% \cdot \mathrm{d}^{-1}\right)$, male gonads $\left(12-30 \% \cdot \mathrm{d}^{-1}\right)$, digestive tract $\left(7-9 \% \cdot \mathrm{d}^{-1}\right)$, skin $(5 \% / \mathrm{d})$, carcass $\left(0.40 .6 \% \cdot \mathrm{d}^{-1}\right)$ and muscle $\left.0.2-0.6 \% / \mathrm{d}\right)$

7. The FSR in the liver of female diploid was almost 2 times higher than in that of the sterile triploids.

8. The FSR in the muscle, carcass and male gonad were lower in the triploids than in the diploids.

9. Mean whole body protein synthesis (WBPS) in the female and male diploids and in the sterile and male triploids was respectively $4.8,3.1,2.0$ and $2.3 \mathrm{~g} / \mathrm{kg} \cdot \mathrm{d}$.

10. The contribution of the muscle to WBPS was greatly lower than that of the liver, the gonad and digestive tract in all the fish studied.
\end{abstract}

\section{INTRODUCTION}

In many species of fish, the development of the gonads is associated with a depletion of muscle and changes of tissues composition (Shulman, 1974; Tveranger, 1985). In the female, the metabolism of liver is stimulated during the vitellogenesis process. The consequences of such changes on nutrition and metabolism are not very well known (Phillips, 1972; Luquet and Watanabe, 1986).

Both weight loss and mortality during the time of sexual maturation could be avoided and thus the production of large fish investigated using sterile fish. Induction of triploidy in salmonids was proposed for this purpose (Chourrout, 1980; Johnston, 1985) and only female triploids are sterile (Solar et al., 1984). Immature triploid trout show a lower growth rate than do diploid trout (Chevassus, 1986). After the spawning period, the body weight in triploid trout is higher than that in diploid trout (Chevassus, 1986). The difference of zootechnical performances and chemical composition between diploid and triploid has been well-analysed especially during sexual maturation but little information on whole body and

*Present address: Fish Physiology Laboratory. I.N.R.A., Campus de Beaulieu, 35042 Rennes Cedex, France

Correspondence to: Benoit Fauconneau, Fish Physiology Laboratory, INRA, Campus de Beaulieu, 35042 Rennes Cedex, France. tissue metabolism of large triploid fish is available.

The aim of the present study was to analyse in diploid and triploid rainbow trout the protein synthesis rate of some tissues and of whole fish during a given time of sexual maturation period. The contribution of different tissue-muscle, skin, liver, digestive tract and gonad-to overall protein synthesis was assessed. The rate of protein synthesis was measured using a large dose injection of labelled $\mathrm{L}$-arginine in order to stabilize the extracellular and intracellular specific activity of that injected amino acid over a given period of time, using the flooding effect (Garlick et al., 1980; Pocrnjic et al., 1983). Arginine was used because it is an essential amino acid in fish and it can be easily analysed.

\section{MATERIALS AND METHODS}

Fish

Two groups of fish were constituted as follows: the eggs of different females were separated into two equal groups and fertilized with the sperm of different males (Choubert and Blanc, 1985). One group was submitted to a heat shock during fertilization (Chourrout, 1980) to induce triploidy, the second group was used as control. After a six month progeny test, the two groups were reared separately in our experimental hatchery (Lees Athas, SW of France) at $8-10^{\circ} \mathrm{C}$. The experiment was conducted at the end of the third year after fertilization, during sexual maturation of the diploid fish (September-October). Throughout this period, the fish were fed $1.3 \%$ body weight/day, one meal per day 
of a commercial diet (Aqualim G.S.O., France). Twenty fish were sampled in each group for the assessment of protein metabolism.

Triploidy was assayed by measurement of nuclear erythrocyte length (major axis) because it had been shown that the volume of erythrocyte, as well as that of erythrocyte nuclei, is significantly different in diploid and triploid rainbow trout (Benfey and Sutterlin, 1984). A sample of blood was used to make a blood smear, the cells were fixed with Giemsa's fixative and the nucleae were stained selectively with blue Grunwald's reagent (methylene blueeosine). Measurements of 10 erythrocytes nucleae per fish were made (Table 1)

Before and after the time of this experiment, 10 fish per group (only for the female diploids and the sterile triploids) were sampled monthly to assess growth rate and changes in body composition (Choubert and Blanc, in preparation).

\section{Fish manipulation and killing}

One hour after the meal, the fish were anesthetized (mono-phenyl-ether of ethylene-glycol, MPEEG $0.4 \mathrm{ml} / 1$ ). They received a single injection of a saline solution $(\mathrm{NaCl}$ $9 \mathrm{~g} / \mathrm{l})$ of $\mathrm{L}-\left[\mathrm{U}-{ }^{14} \mathrm{C}\right]$-arginine (CEA, France) in the caudal vein. In each fish $1.1 \mathrm{ml}$ of this solution $(0.45$ mmoles of arginine $/ \mathrm{ml}$ and $532.8 \mathrm{kBq} / \mathrm{ml}$ ) yielded exactly 0.53 and $0.61 \mathrm{mmol} / \mathrm{kg}$ of arginine and 310.8 and $351.5 \mathrm{kBq} / \mathrm{kg}$ respectively in the diploid and triploid trout.

The fish were placed in individual tanks supplied with free running water for 30 or $120 \mathrm{~min}$. At the end of these periods, the fish were caught and anesthetized (MPEEG $0.4 \mathrm{ml} / \mathrm{l}$ ). A sample of blood $(3-4 \mathrm{ml} / \mathrm{kg})$ was withdrawn and centrifuged. The plasma was collected and frozen until analysis. The liver was rapidly removed, rinsed in a cold saline solution $(\mathrm{NaCl}, 9 \mathrm{~g} / \mathrm{l})$, dried on an absorbent paper, and frozen in liquid nitrogen. The digestive tract was removed, emptied, and the internal part was rinsed gently first with distilled water, and then with cold trichloracetic acid solution (TCA $10 \% \mathrm{v} / \mathrm{v}$ ). The gonads were removed. A piece of the skin was removed from the dorsal part of the fish. The main part $(95 \%)$ of the epaxial musculature was removed by dissection. All the tissues and the carcass were weighed, frozen in liquid nitrogen as soon as possible and stored at $-25^{\circ} \mathrm{C}$ until further analysis. The total procedure did not exceed $15 \mathrm{~min}$.

\section{Tissue treatments}

The tissues were ground in liquid nitrogen and an aliquot fraction of $5 \mathrm{~g}$ was weighed. These samples were treated to extract free and protein-bound arginine as already described (Fauconncau et al., 1986a). The remainder of each tissue was freeze-dried.

The lipids were extracted from freeze-dried samples of tissues, by three successive extraction with methanol/ chloroform solution $(2: 1 \mathrm{v} / \mathrm{v})$ and measured by weighing. The lipids were then dissolved in acetone and the total radioactivity was measured in the acetone solution.

The nitrogen and energy content of pooled samples of freeze-dried tissues was measured respectively by the Kjeldahl method and by calorimetry using an adiabatic calorimeter. The protein content was assessed from the nitrogen content assuming that the nitrogen content of protein is $16 \%$

\section{Extraction of free amino acid and protein}

The tissues and plasma were first homogenized (Polytron) in a trichloroacetic acid solution (TCA $10 \% \mathrm{v} / \mathrm{v}$ ) for $1.5 \mathrm{~min}$ and then centrifuged $\left(5000 \mathrm{~g}, 15 \mathrm{~min}, 0^{\circ} \mathrm{C}\right)$. The supernatant was collected. This procedure was repeated four times. The successive supernatant or acid-soluble fractions were pooled. The acid was removed from these fractions by three successive homogenizations in diethyl ether and decantations. The aqueous solution was then concentrated $(10 \mathrm{ml})$ by moderate heating $\left(40^{\circ} \mathrm{C}\right)$ under vacuum. This concentrate, called acid-soluble fraction, contained the free amino acid and the catabolites of the amino acids as well as other soluble metabolites.

The acid-insoluble residue was neutralized by homogenization in sodium acetate/methanol solution $(120 \mathrm{~g} / 1, \mathrm{pH} 7.0)$ and centrifugation $\left(5000 \mathrm{~g}, 15 \mathrm{~min}, 0^{\circ} \mathrm{C}\right)$. The lipids in the residue were extracted by two successive treatments $(\mathrm{l} \mathrm{hr}$ and $20 \mathrm{hr})$ with a methanol/chloroform solution $(2 \mathrm{v} / \mathrm{l} \mathrm{v})$. The residue was filtered (GF/A filters, $1.7 \mu \mathrm{m}$, Whatmann), washed with ethanol and diethyl-ether. The residue was left for $48 \mathrm{hr}$ in a desiccator under vacuum, then ground and stored at $-20^{\circ} \mathrm{C}$. This residue, called acid-insoluble extract or protein extract contained the protein and the nucleic acids. An aliquot sample of this powder $(20 \mathrm{mg})$ was submitted to acid hydrolysis $\left(\mathrm{HCl} 5.5 \mathrm{~N}, 125^{\circ} \mathrm{C}, 24 \mathrm{hr}\right)$. The acid from this solution was removed by several evaporations under vacuum, and by rinsing with distilled water, to obtain a final volume of $10 \mathrm{ml}$

\section{Separation of free arginine and protein-bound arginine}

Arginine was separated from the other amino acids and from its catabolites by application on a cation exchange resin (Amberlite CG 50 in $\mathrm{Na}^{+}$form, $\mathrm{pH} \mathrm{8.0)}$ (Wu, 1959). An aliquot $(1 \mathrm{ml})$ of the acid soluble fraction or of the protein hydrolysate was applied on $1 \mathrm{ml}$ of resin. The arginine catabolites (especially guanidino-acetic acid) and the other amino acids were eluted by distilled water Arginine was then eluted with sodium acetate solution $(0.5 \mathrm{M})$. The quality of arginine separation was controlled in each batch of resin by the application of a standard containing $\mathrm{L}-\left[\mathrm{U}^{14} \mathrm{C}\right]$-arginine (CEA, France) diluted in a standard hydrolysate ( 18 amino acids, Pierce Chemical Co.). With standards containing $25-250 \mathrm{nmol} / \mathrm{ml}$ of arginine, morc than $95 \%$ of the arginine was collected in the second eluate. The level of arginine in the samples ranged from 10 to $700 \mathrm{nmol} / \mathrm{ml}$. In these samples, the percentage of radioactivity collected in the first eluate gave an estimate of the amount of catabolites in the labelled arginine.

The amount of arginine was measured in the second eluate with the automated version (Bacchus and London, 1971) of the Sakaguchi method (1951). The specific activity of arginine was assessed by the ratio between the radioactivity collected in the second eluate and the level of arginine in the eluate. In the protein hydrolysate the level of arginine was very high and the level of radioactivity was very low, so the specific activity of the protein-bound arginine was assessed with a high error. In the protein extract, the amount of radioactivity found in compounds other than arginine was under $5 \%$. Thus, the specific activity of arginine in the protein was calculated by the ratio between the total amount of radioactivity in the protein extract, and the level of arginine in that extract.

Table 1. Mean erythrocytes nuclear length $(\mu \mathrm{m})$ in diploid $(2.1 \mathrm{~kg}$ body wt) and triploid ( $1.8 \mathrm{~kg}$ body wt) rainbow trout (Salmo gairdneri $\mathbf{R}$.)

\begin{tabular}{lcccccc}
\hline & \multicolumn{3}{c}{ Diploids } & \multicolumn{3}{c}{ Triploids } \\
& Mean & SD & $N$ & Mean & SD & $N$ \\
\hline Male & 5.33 & 0.38 & 9 & 7.04 & 0.16 & $8^{*}$ \\
Female or sterile & 5.06 & 0.25 & 11 & 6.98 & 0.42 & $12^{*}$ \\
Mean & 5.18 & 0.32 & 20 & 7.01 & 0.34 & $20^{*}$ \\
\hline
\end{tabular}

*Differences were significant $(P<0.001)$ 
Due to a higher proportion of arginine catabolites in the acid-soluble fraction of liver than in that of other tissues, the arginine was further extracted by an alternative ion exchange chromatography. Samples $(1 \mathrm{ml})$ of the liver acidsoluble fraction were applied on a cation exchange resin ( $2 \mathrm{ml}$ of Dowex $50 \mathrm{~W} 2 \times 8, \mathrm{H}^{+}$form, $\mathrm{pH} 5.5$ ) according to the procedure of Adibi et al. (1975). The first eluate $(6 \mathrm{ml}$ of $\mathrm{HCl} 0.02 \mathrm{~N}$ ) contained the organic acids, the second eluate $\left(7 \mathrm{ml}\right.$ of $\mathrm{NH}_{4} \mathrm{OH} 2 \mathrm{~N}$ ) contained the acidic and neutral amino acids and the third eluate $\left(8 \mathrm{ml}\right.$ of $\mathrm{NH}_{4} \mathrm{OH}$ $4 \mathrm{~N}$ ) contained arginine and the other basic amino acids. An estimation of the specific activity of arginine was obtained by the ratio between the total radioactivity in the third eluate and the arginine content in that eluate.

\section{Extraction and measurement of nucleic acids}

The procedure used to extract RNA and DNA (Schmidt and Thannhauser, 1945, modified by Munro and Fleck, 1966) has succesfully been used in fish by Luquet and Durand (1970). The RNA was extracted from the acid-insoluble extract by a basic hydrolysis $\left(\mathrm{KOH} 0.3 \mathrm{~N}, 37^{\circ} \mathrm{C}\right)$ for $15 \mathrm{hr}$. Then, the solution was cooled $\left(0^{\circ} \mathrm{C}\right)$ and neutralized. The DNA was precipitated by acidification with $\mathrm{HClO}_{4}$ $1.2 \mathrm{~N}$ and by centrifugation $(5000 \mathrm{~g}, 15 \mathrm{~min})$. The residue was washed twice with $\mathrm{HClO}_{4} 0.2 \mathrm{~N}$. The combined supernatant contained the RNA.

The DNA was extracted from the residue by acid hydrolysis $\left(\mathrm{HClO}_{4} 0.5 \mathrm{~N}, 90^{\circ} \mathrm{C}, 1 \mathrm{hr}\right)$. After centrifugation $(5000 \mathrm{~g}$, 30 min), the supernatant was collected. A second hydrolysis was performed on the residue. The combined supernatant contained the DNA.

The RNA was measured colorimetrically with orcinol (Herbert et al., 1971) using yeast RNA (Sigma Chemical) as a standard. The DNA was also measured colorimetrically with diphenylamine (Burton, 1956) using salmon sperm DNA as a standard (Sigma Chemical). The yield of extraction of the RNA and DNA, tested by the addition of a given amount of a standard in some samples, was 96 and $95 \%$ respectively.

\section{Measurement of radioactivity}

The radioactivity was measured by liquid scintillation counting ( $\beta$-Matic II, Roche-Kontron S.A.) and expressed as disintegration per minute (DPM). The aqueous samples were adjusted to a total volume of $5 \mathrm{ml}$ and mixed with $10 \mathrm{ml}$ of the liquid scintillation reagent (Instagel, Packard) to obtain a gel. To measure the radioactivity in the protein extract, the powder was first dissolved in a basic solution ( $\mathrm{NaOH} 0.8 \mathrm{~N}, 37^{\circ} \mathrm{C}, 12 \mathrm{hr}$ ).

\section{Calculation of protein synthesis rate in different tissues}

The rate of protein synthesis $k s$ (in $\% . \mathrm{d}^{-1}$ ) in tissues and in whole body was calculated according to Garlick et al. (1980), using the equation:

$$
k s=\frac{S b(t 2)-S b(t 1)}{\frac{1}{2}(S a(t 1)+S a(t 2))} \times \frac{100}{t 2-t 1}
$$

where $t 1$ and $t 2$ are two times of incubation after the injection. $S a(t)$ and $S a(t 2)$ the respective specific activities of the amino acid in the soluble pool of the tissue and $S b(t)$ and $S b(t 2)$ the respective specific activities of the amino acid in the protein of the tissue.

In the above equation, the variability of $S a$ is not used for the calculation of $k s$ but by integrating equation (1), $k s$ can be calculated by plotting $S b$ and $S a$ according to the following equation (Attaix et al., 1987):

$$
100 \times S b(t)=k s \cdot(S a(t) \times t)+100 \times S b(t 0) .
$$

The comparisons between $k s$ values were made by covariance analysis. The statistical significance of differences between the groups of fish were assessed by ANOVA analysis (Snedecor and Cochran, 1971). Then the significance of the differences between the mean in two groups were tested by Student $t$-test.

\section{RESULTS}

\section{Composition of the diploid and triploid trout}

The proportions of the different tissues were expressed as percentages of body weight without the gonads to take into account that some of the triploids were sterile (Table 2).

Within the diploid trout, the body weight of the males was slightly lower than that of the females but this difference was not significant. The relative proportions of the muscle and liver in the female diploids were significantly higher than those of the male diploids. The mean empty body weight of the triploids was significantly lower $(-2 \%)$ than that of the diploids. The size of the gonads in the male triploids was similar to that in the male diploids. The relative proportions of the muscle in the sterile triploids and the male triploids were significantly different but similar to those of the female and male diploids. The relative proportion of the digestive tract in the stcrilc triploids was significantly higher than that in the mature diploids.

The protein $(N \times 6.25)$ and lipid contents measured in pooled samples of some selected tissues in each group are reported on Fig. 1. The lipid content in the muscle and liver of the female diploids was lower than the same in fish of the other groups. The protein content in the digestive tract was very low in the triploids as compared with the diploids. The lipid and energy content in the digestive tract was higher in the triploids than in the diploids.

\section{Nucleic acids in the different tissues}

The DNA and RNA contents were measured in some selected tissues on pooled samples (Table 3). The amount of DNA was similar in the diploid and triploid muscle, and similar in the diploid and triploid liver of the same sex (sterile triploids assimilated to females). The DNA content in the triploid digestive tract was higher than that of diploids. The content of DNA in the male liver was higher than that of the

\begin{tabular}{|c|c|c|c|c|c|c|c|c|c|c|}
\hline & \multirow{2}{*}{\multicolumn{2}{|c|}{$\begin{array}{c}\text { Gonado-somatic } \\
\text { muscle }\end{array}$}} & \multirow{2}{*}{\multicolumn{2}{|c|}{$\begin{array}{l}\text { Body weight } \\
\text { without gonads }\end{array}$}} & \multicolumn{6}{|c|}{ Composition (in $\%$ body weight without gonads) } \\
\hline & & & & & \multicolumn{2}{|c|}{ Latero-dorsal muscle } & \multicolumn{2}{|c|}{ Digestive tract } & \multicolumn{2}{|c|}{ Liver } \\
\hline & Mean & SD & Mean & SD & Mean & SD & Mean & SD & Mean & SD \\
\hline \multicolumn{11}{|l|}{ Diploids } \\
\hline Females $N=11$ & 6.3 & 1.1 & $2038^{\mathrm{a}}$ & 330 & $53.6^{\mathrm{a}}$ & 4.3 & $7.3^{\mathrm{a}}$ & 1.1 & $2.7^{\mathrm{a}}$ & 0.4 \\
\hline Males $N=9$ & 5.0 & 1.9 & $1922^{\mathrm{ab}}$ & 192 & $49.4^{\mathrm{b}}$ & 2.8 & $7.7^{\mathrm{a}}$ & 1.7 & $1.4^{b}$ & 0.1 \\
\hline \multicolumn{11}{|l|}{ Triploids } \\
\hline Sterile $N=12$ & - & - & $1786^{\mathrm{ab}}$ & 323 & $52.7^{\mathrm{a}}$ & 2.1 & $10.5^{b}$ & 2.6 & $1.5^{\mathrm{b}}$ & 0.4 \\
\hline Male $N=8$ & 5.4 & 1.8 & $1673^{\mathrm{b}}$ & 168 & $49.6^{b}$ & 1.5 & $7.1^{\mathrm{a}}$ & 1.5 & $1.3^{\mathrm{b}}$ & 0.2 \\
\hline
\end{tabular}

Table 2. Relative tissue composition of diploid and triploid rainbow trout in the course of sexual maturation

Data indicated by different letter within each tissue were significantly different $(P<0.01)$. 


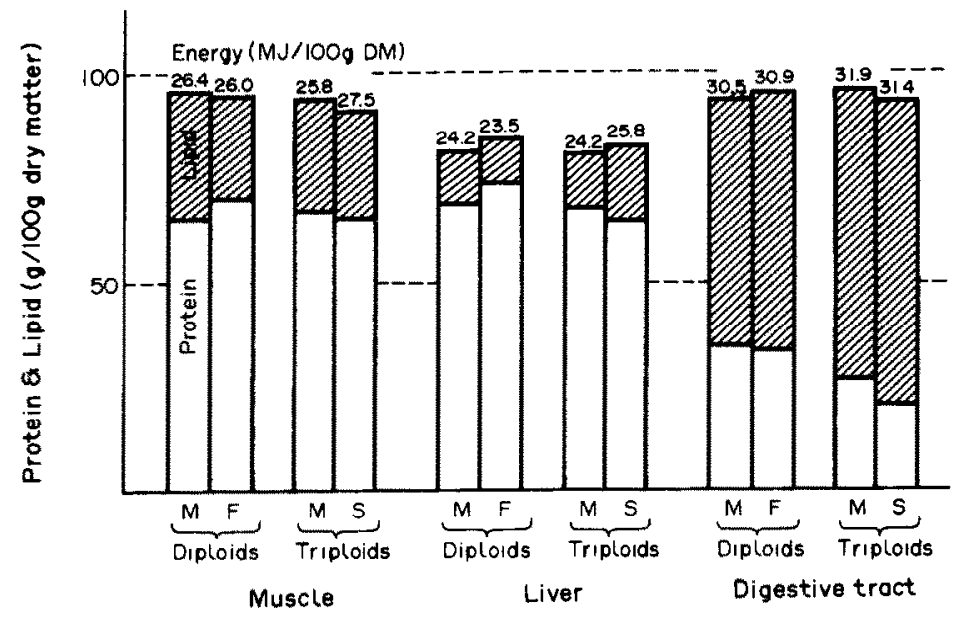

M: Male, F: Female, S: Sterile

Fig. 1. Protein (open bars), lipid (hatched bars) and energy (figures at the top of the bars) content (respectively in $\mathrm{g}$ and $\mathrm{MJ}$ per $100 \mathrm{~g}$ of dry matter) in different tissues: muscle, liver, digestive tract of diploid and triploid rainbow trout $(1.8-2.1 \mathrm{~kg}$ body $\mathrm{wt})$. Results are the mean of three determinations on pooled samples in each group.

female diploids and sterile triploids. Finally, the DNA content in the male gonad was twice as low in the triploids as it was in the diploids.

The RNA content of the muscle was higher in the male than in the female diploid and sterile triploids, but it was not different between trout of the same sex. The amount of RNA in the female diploid liver was higher $(+50 \%)$ than in that of the other groups. The RNA content in the triploid male gonad was higher than that of the male diploids. The amount of DNA and RNA in the female gonad was very much lower than that in the male gonad.
Free arginine levels in the different tissues (Table 4) following high dose injection of L-arginine $(0.5-0.6 \mathrm{mmol} / \mathrm{kg})$

The level of free arginine in the plasma was higher than in the muscle, liver, carcass and skin and lower than in the digestive tract and male gonad. Between 30 and $120 \mathrm{~min}$ after the injection, the level of free arginine decreased in the plasma of the diploids and triploids and in the muscle, carcass and digestive tract of the diploids. The level of free arginine in the whole trout was higher in the male diploids and triploids,

Table 3. Mean DNA and RNA content (in mg of DNA and RNA per $\mathrm{g}$ of protein extract) in different tissues of diploid and triploid rainbow trout in the course of sexual maturation (each datum was the mean of 4 determinations)

\begin{tabular}{|c|c|c|c|c|c|c|c|c|c|c|}
\hline & \multicolumn{2}{|c|}{ Muscle } & \multicolumn{2}{|c|}{ Liver } & \multicolumn{2}{|c|}{ Digestive tract } & \multicolumn{2}{|c|}{ Gonads } & \multicolumn{2}{|c|}{ Skin } \\
\hline & DNA & RNA & DNA & RNA & DNA & RNA & DNA & RNA & DNA & RNA \\
\hline $\begin{array}{l}\text { Diploids } \\
\text { Female } \\
\text { Male }\end{array}$ & $\begin{array}{l}1.1^{\mathrm{a}} \\
1.0^{\mathrm{a}}\end{array}$ & $\begin{array}{r}9.1^{\mathrm{a}} \\
10.8^{\mathrm{a}}\end{array}$ & $\begin{array}{r}8.4^{a} \\
11.4^{b}\end{array}$ & $\begin{array}{l}80.2^{d} \\
52.2^{b}\end{array}$ & $\begin{array}{l}5.2^{\mathrm{a}} \\
5.8^{\mathrm{a}}\end{array}$ & $\begin{array}{l}54.3^{\mathrm{a}} \\
52.1^{\mathrm{a}}\end{array}$ & $\begin{array}{r}0.5^{\mathrm{a}} \\
241.3^{\mathrm{b}}\end{array}$ & $\begin{array}{r}8.2^{\mathrm{a}} \\
28.1^{\mathrm{b}}\end{array}$ & $\begin{array}{l}2.8^{\mathrm{a}} \\
2.9^{\mathrm{a}}\end{array}$ & $\begin{array}{l}14.2^{\mathrm{a}} \\
24.0^{\mathrm{a}}\end{array}$ \\
\hline $\begin{array}{c}\text { Triploids } \\
\text { Sterile } \\
\text { Male }\end{array}$ & $\begin{array}{l}0.9^{\mathrm{a}} \\
1.0^{\mathrm{a}}\end{array}$ & $\begin{array}{r}8.8^{a} \\
10.6^{a}\end{array}$ & $\begin{array}{r}8.0^{4} \\
13.6^{b}\end{array}$ & $\begin{array}{l}55.3^{b} \\
50.9^{b}\end{array}$ & $\begin{array}{l}6.9^{\mathrm{a}} \\
8.0^{\mathrm{a}}\end{array}$ & $\begin{array}{l}56.8^{a} \\
40.0^{b}\end{array}$ & $124.6^{b}$ & $\overline{36.8^{b}}$ & $\begin{array}{l}\text { ND } \\
\text { ND }\end{array}$ & $\begin{array}{l}\mathrm{ND} \\
\mathrm{ND}\end{array}$ \\
\hline
\end{tabular}

In each tissue data indicated by different superscripts were significantly different $(P<0.05)$.

Table 4. Free arginine content (in $\mu$ moles $\cdot g^{-1}$ tissue) and specific activity of free arginine in different tissues of female diploid tainbow trout, at two time points after injection of a large dose of $\mathrm{L}-\mathrm{U}^{44} \mathrm{C}$-arginine $\left(0.5 \cdot 0.6 \mathrm{mmol} / \mathrm{kg}^{-1}, 33.2 \mathrm{dpm} \cdot \mathrm{mmoles}{ }^{-3}\right)$

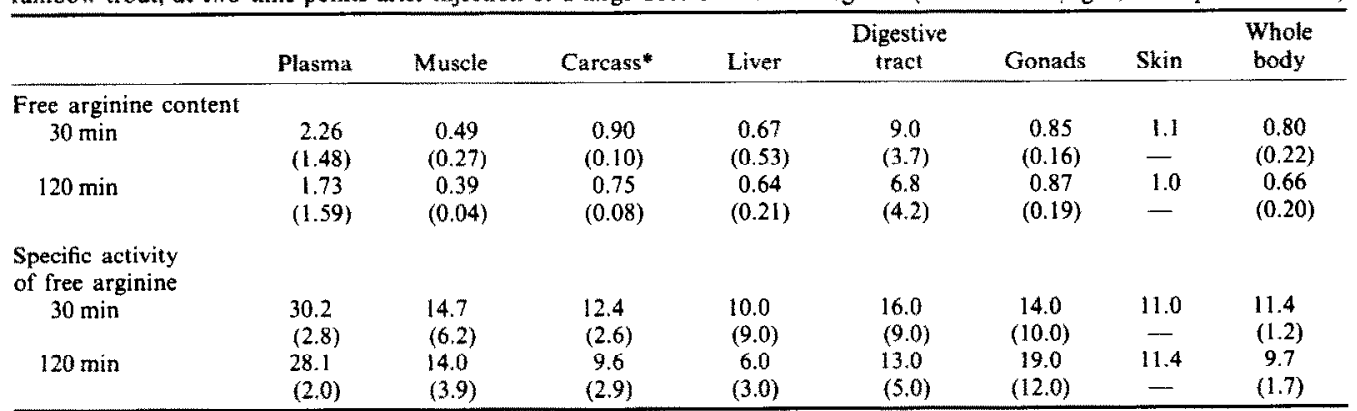

* Carcass without muscle.

Differences between 30 and $120 \mathrm{~min}$ are significantly different $(P<0.05)$

( ) Standard deviation. 
Table 5. Fractional rate of protein synthesis $\left(\% \cdot d^{-1}\right)$ in different tissues of diploid and triploid rainbow trout in the course of sexual maturation

\begin{tabular}{|c|c|c|c|c|c|c|c|}
\hline & Muscle & Carcass & Liver & $\begin{array}{l}\text { Digestive } \\
\text { tract }\end{array}$ & Gonads & Skin & $\begin{array}{l}\text { Whole } \\
\text { body }\end{array}$ \\
\hline \multicolumn{8}{|l|}{ Diploid } \\
\hline \multirow[t]{2}{*}{ Female } & $0.38^{\mathrm{z}}$ & $0.63^{3}$ & $43.7^{\mathrm{a}}$ & $6.9^{\mathrm{a}}$ & 0.68 & $1.84^{\mathrm{a}}$ & $2.09^{\sharp}$ \\
\hline & $(0,02)$ & $(0.10)$ & $(7.2)$ & $(0.6)$ & $(0.11)$ & $(1.17)$ & $(0.16)$ \\
\hline \multirow[t]{2}{*}{ Male } & $0.59^{b}$ & $0.48^{b}$ & $28,6^{\mathrm{b}}$ & $7.0^{\mathrm{a}}$ & $31.3^{\mathrm{a}}$ & $1.19^{\mathrm{a}}$ & $2.10^{\mathrm{a}}$ \\
\hline & $(0.03)$ & $(0.04)$ & $(7.2)$ & (1.1) & $(4.5)$ & $(0.90)$ & $(0.17)$ \\
\hline \multicolumn{8}{|l|}{ Triploid } \\
\hline \multirow[t]{2}{*}{ Sterile } & $0.23^{\circ}$ & $0.61^{*}$ & $16.3^{c}$ & $9.2^{b}$ & - & $1.09^{\sharp}$ & $1.07^{b}$ \\
\hline & $(0.03)$ & $(0.05)$ & $(2.3)$ & $(1.0)$ & & $(0.17)$ & $(0.12)$ \\
\hline \multirow[t]{2}{*}{ Male } & $0.26^{6}$ & $0.43^{6}$ & $30.8^{b}$ & $9.0^{6}$ & $12,7^{b}$ & 1.38 & $1.37^{6}$ \\
\hline & $(0.03)$ & $(0.04)$ & $(7.7)$ & $(0.9)$ & $(3.5)$ & - & $(0.21)$ \\
\hline
\end{tabular}

() Standard deviation.

Values indicated by different letters within each tissue are significantly different $(P<0.01)$.

0.94 and $0.69 \mu \mathrm{mol} / \mathrm{g}$ respectively, than in the female diploids and sterile triploids, 0.73 and $0.58 \mu \mathrm{mol} / \mathrm{g}$. respectively.

Total radioactivity collected in the different tissues after the injection of $L-\left[U-{ }^{14} C\right]$-arginine

More than $70 \%$ of the radioactivity injected was collected in the acid-soluble and acid-insoluble fractions of the whole trout. A small amount of the radioactivity was measured in the lipid: $1.7-3.4 \%$ of the radioactivity injected. The amount of radioactivity measured in the lipid of the triploids $(3.0 \%$ of the injected dose) was higher than that of the diploids. $(1.9 \%)$. The radioactivity in the lipid of the viscera of the sterile triploids was more than twice that of fish in the other groups. More than $50 \%$ of the lipid radioactivity was in the carcass.

\section{Catabolites of labelled arginine in the different tissues}

The proportion of radioactivity measured in compounds other than arginine in the acid-soluble fraction of the plasma, muscle, carcass, skin and gonads was below $20-25 \%$. In the male diploids and triploids, the percentage of catabolites in the digestive tract and in the liver were respectively higher than $25 \%$ and $40 \%$. These percentages of the soluble arginine catabolites were lower in the liver and digestive tract of the female diploids than in those of the other groups.

Specific activity of free arginine in the different tissues and in the whole trout after the injection of $L-\left[U-{ }^{14} C\right]-$ arginine (Table 4)

The specific activity of free arginine in the plasma was not very different from that of arginine in the dose injected (33 DPM/nmole). The specific activities (SA) of free arginine in the tissues were 2-3 times lower than those in plasma. There were no significant differences between the different groups in the specific activities of arginine in each tissue.

Rate of protein synthesis in the different tissues and in the whole trout (Table 5)

The rate of protein synthesis was lower in the muscle, female gonad and carcass than in the other tissues such as the liver, digestive tract, skin and male gonad. Muscle protein synthesis rate of the female diploids and sterile triploids was lower than that of the male diploids and triploids. Protein synthesis rate in the muscle, carcass, skin and male gonad of the triploids was lower than that of the diploids of the same sex. On the contrary, digestive tract protein synthesis rate of the triploids was similar and even slightly higher than that of the diploids. Finally, liver protein synthesis rate of the female diploids was almost two times higher than that of the male diploids and triploids.

The fractional rate of protein synthesis in the whole body was calculated using SA of free arginine in the different tissues and the relative contribution of individual tissues to whole body free arginine for assessment of whole body SA of free arginine and $\mathrm{SA}$ of protein-bound arginine and the relative contribution of individual tissues to whole body protein to assess whole body SA of protein-bound arginine. Whole body protein synthesis rate was higher in the female diploids than in the male diploids and lower in the sterile triploids than in the male triploids, but these differences were not significant.

Table 6. Absolute amounts of protein synthesized ( $\mathrm{g}$ protein $\cdot \mathrm{kg}^{-1} \cdot \mathrm{d}^{-1}$ ) in different tissues of diploid and rainbow trout in the course of sexual maturation

\begin{tabular}{ccccccc}
\hline & Muscle & Carcass & Liver & $\begin{array}{c}\text { Digestive } \\
\text { tract }\end{array}$ & Gonads & $\begin{array}{c}\text { Whole } \\
\text { body }\end{array}$ \\
\hline Diploid & & & & & & \\
Female & $0.21^{\mathrm{a}}$ & $0.32^{\mathrm{a}}$ & $1.24^{\mathrm{a}}$ & $0.11^{\mathrm{a}}$ & $0.07^{\mathrm{a}}$ & $1.95^{\mathrm{a}}$ \\
& $(0.01)$ & $(0.05)$ & $(0.21)$ & $(0.01)$ & $(0.01)$ & $(0.14)$ \\
Male & $0.26^{\mathrm{b}}$ & $0.24^{\mathrm{b}}$ & $0.42^{\mathrm{b}}$ & $0.12^{\mathrm{a}}$ & $1.96^{\mathrm{b}}$ & $3.00^{\mathrm{b}}$ \\
& $(0.01)$ & $(0.02)$ & $(0.11)$ & $(0.02)$ & $(0.28)$ & $(0.25)$ \\
Triploid & & & & & & \\
Sterile & $0.13^{\mathrm{c}}$ & $0.25^{\mathrm{b}}$ & $0.21^{\mathrm{c}}$ & $0.08^{\mathrm{b}}$ & - & $0.74^{\mathrm{c}}$ \\
& $(0.02)$ & $(0.02)$ & $(0.03)$ & $(0.01)$ & & $(0.08)$ \\
Male & $0.12^{\mathrm{c}}$ & $0.27^{\mathrm{b}}$ & $0.38^{\mathrm{b}}$ & $0.10^{\mathrm{ab}}$ & $0.59^{\mathrm{b}}$ & $1.59^{\mathrm{a}}$ \\
& $(0.02)$ & $(0.03)$ & $(0.09)$ & $(0.01)$ & $(0.16)$ & $(0.24)$ \\
\hline
\end{tabular}

( ) Standard deviation.

Values indicated by different letters within each tissue are significantly different $(P<0.01)$. 
The rate of protein synthesis observed in the different tissues (Table 5) was correlated with the RNA/protein ratio (Table 3): slope $=1.0, r^{2}=0.97$, $N=12$, if the results obtained on the liver of females were excluded.

Whole body protein synthesis and contribution of different tissues (Table 6)

Whole tissue protein synthesis was calculated using tissues FSR and protein concentration and the relative size of individual tissues. It was also calculated for whole body.

The whole body protein synthesis (WBPS) was higher in the female diploids: $1.3 \mathrm{~g}$ protein $/ \mathrm{kg}$ body weight/day than in the male diploid: $0.8 \mathrm{~g} / \mathrm{kg} / \mathrm{d}$ and the triploids: $0.9 \mathrm{~g} / \mathrm{kg} / \mathrm{d}$.

Total protein synthesis in the muscle, female gonad and trout remains of the diploids was lower than in the liver of male and female diploids, digestive tract and male gonad (Table 6). Differences between total protein synthesis in the tissues were similar in the triploids with lower figures in the muscle, male gonads and trout remains. Thus, the contribution of the muscle to the WBPS was low (below 10\%) when compared to its contribution to the whole body protein content.

\section{DISCUSSION}

\section{Validity of the method}

The method of injection of a large dose of an amino acid (Garlick et al., 1980) was used to flood the intracellular pool of the different tissues with a labelled amino acid so that its specific activity is stabilized during a given period of time. In this experiment, the amount of arginine injected: $0.5-0.6 \mathrm{mmol} / \mathrm{kg}$ (Haschemeyer, 1983; Pocrnjic et al., 1983; Houlihan et al., 1986) was large enough to increase the free arginine content in the plasma up to ten times and that in the muscle and liver up to two or three times the normal level of arginine in these tissues (Gras et al., 1978; Medale et al., 1987). Within two hours after the injection the SA of free arginine in the different tissues was stabilized. Thus the theoretical conditions of a flooding effect were realized according to the level of unlabelled arginine.

Another goal of the method is to reach, in the different tissues, the same specific activity as that in the plasma and, theoretically, as that in the injected dose. Loughna and Goldspink (1985) postulated that it is not possible to obtain such an effect in fish, because the rates of distribution and transport of free amino acids are lower in fish than in mammals. In fact, with a relatively low dose of amino acid injected $(0.5 \mathrm{mmol} / \mathrm{kg})$, the specific activity of the labelled amino acid in the muscle and liver was lower than that in the plasma (Pocrnjic et al., 1983; Houlihan et al., 1986) and in this experiment the SA in the tissues was around $50 \%$ that in the plasma. The arginine solution injected $(960 \mathrm{mM}$, in a small volume $1 \mathrm{ml})$ have effectively swamped the plasma, but may have been selectively withdrawn by some tissues, the liver, digestive tract and gill and then actively catabolized or excreted. It was supposed that such stimulation of amino acid catabolism, which occurs also with a large dose injection of phenylalanine, did not have any effect on protein synthesis.

Finally, the results obtained should be more related to those of an infusion of a trace dose of an amino acid with a stabilization of the specific activity of the amino acid in the precursor pool for protein synthesis. The main consequence on the validity of our results was that protein synthesis rate could be overestimated as is the case for other results obtained with the infusion method (Smith, 1981; Loughna and Goldspink, 1984).

\section{Protein metabolism in large fish}

The general pattern of protein synthesis in the different tissues of trout, i.e. high rates of protein synthesis (more than $10 \% / d$ ) in the active organs such as the liver, digestive tract and male gonad and very low rates of protein synthesis (below $0.5 \% / \mathrm{d}$ ) in the white muscle, was similar to that generally observed in fish (Fauconneau, 1985; Houlihan et al., 1986).

The rate of protein synthesis observed in the different tissues (muscle, digestive tract and liver) and in the whole trout was similar and even lower in this experiment than that observed in growing trout (Smith, 1981; Fauconneau and Arnal, 1985; Loughna and Goldspink, 1984, 1985; Houlihan et al., 1986). These differences could be related to the decrease in the proteosynthetic activity of fish with aging (Fauconneau, 1985; Houlihan et al., 1986). In the muscle, using our data and other available data (Fauconneau et al., 1981; Smith, 1981; Houlihan et al., 1986), a linear relationship was drawn between the fractional protein synthesis rate of the muscle and the specific growth rate of the whole fish (Fig. 2). It means that from $100 \mathrm{~g}$ to $2 \mathrm{~kg}$ a decrease in the specific growth rate of the whole trout, is linked to a decrease in the FSR of the muscle. The slope of this linear regression (1.8), was close to that calculated in growing pigs (2.2) and in growing malnourished children (1.4) (Young et al., 1985). Thus in trout, high rates of protein deposition (accretion) in the muscle and consequently in the whole trout could be achieved with higher yield than that in fast-growing mammals but not as high as that in recovering malnourished children.

\section{Protein metabolism in diploids during sexual maturation}

In the female, the growth of the gonad was compensated for by a decrease in the proportion of the digestive tract and whole eviscerated carcass. As already described by Tveranger (1985), fat content in the muscle and remains was lower in the female than in the male. The fractional rate of protein synthesis of muscle was also greatly reduced $(60 \%)$ in the female as compared with the male but this was not the case as regards the digestive tract, trout remains and skin.

In the female, during the phase of vitellogenesis a large increase in the activity of the liver is observed with a very high stimulation of the protein synthesis machinery for the synthesis of vitellogenin (Bohemen et al., 1981). This was true in our experiment where the females, as compared to the males, had a higher hepatosomatic index $(+80 \%)$, a slightly lower size of hepatocytes $(+30 \%$ of DNA content) and a higher 


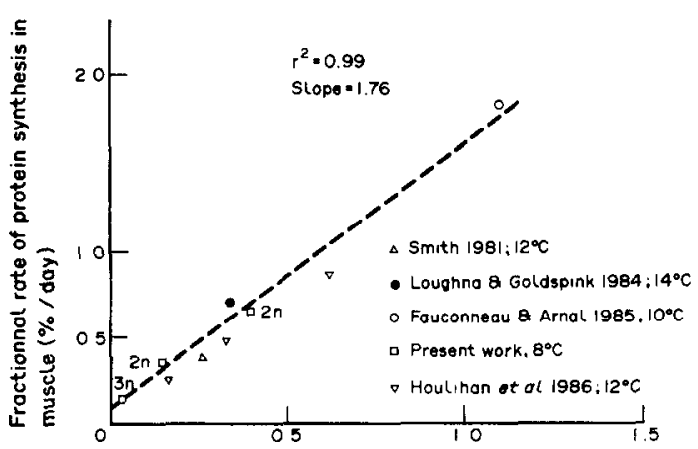

Specific growth rote of whole fish in rainbow trout (Salmo gairdneri R.) (\%/d)

Fig. 2. Relationship between fractional rate of protein synthesis in white muscle and specific growth rate of whole body in rainbow trout at different body weights.

activity (total RNA content and total amount of protein synthesized respectively 3 and 4 times higher). More than $50 \%$ of whole body protein synthesis was directed toward the synthesis of protein in the liver. Such changes in the liver are under the control of oestrogens (Bohemen et al., 1982; Haux and Norberg, 1985; Maitre et al., 1985).

In the male diploids which expressed a higher specific growth rate $(0.6 \% / d)$ than that of the females, the build-up of gonad was nearing completion (some of the males were spermiating). The rate of protein synthesis in the gonads was as high as that in the liver and digestive tract. Thus, more than $60 \%$ of whole body protein synthesis was being carried out in the "visceral tissues" (liver, digestive tract and gonads), and only a small part in the muscle (10-20\%), even if the fractional rate of protein synthesis in muscle was as high as that observed in $200 \mathrm{~g}$ trout (Loughna and Goldspink, 1985).

\section{Protein metabolism in triploid trout}

The relative proportion of tissues and the body composition of male triploid and diploid were similar (Lincoln and Scott, 1984). The most important differences were oberved between female diploid and sterile triploid with respect to the size and protein content of liver and the size and lipid content of digestive tract. The same differences in lipid content of triploid and diploid mature trout have been reported (Lincoln and Scott, 1984; Chevassus, 1986) and this was observed especially in the digestive tract. The activity of adipose cells of the perivisceral fat might explain the fact that in the digestive tract, the fractional rate of protein synthesis in the triploids was similar to that in the diploids, when it was lower in the muscle. The orientation of the metabolism of sterile triploids toward lipogenesis in visceral tissues should have been a consequence of the alteration of the hormonal state of these fish. The absence of circulating oestradiol and the low level of circulating testosterone (Lincoln and Scott, 1984) might have altered utilization of substrate in these fish (Habibi and Ince, 1983).

The DNA and RNA contents in the different tissues, and especially in the muscle, of the triploids and the diploids were similar. Thus, it was concluded that cell size and the amount of muscle syncitium controlled by a nuclear were higher in the triploids than in the diploids. This has only been demonstrated by histological observations in the gonad (Lincoln and Scott, 1984; Solar et al., 1984). These differences are not associated with any significant alteration in the energy metabolism and in the nitrogen budget of triploids (Benfey and Sutterlin, 1984; Oliva-Teles and Kaushik, 1985; Fauconneau et al., 1986). But the proteosynthetic activities of the different tissues (absolute rate of protein synthesis and protein synthesis per unit DNA or unit RNA) were lowered in the triploids compared to that in the diploids. This could explain also the lower growth rates $(-10$ to $-15 \%$ ) of triploids as compared with the diploids (Chevassus, 1986).

Acknowledgements - This work was supported by a grant from IFREMER (Accord Cadre INFRA-IFREMER 85-86). The authors wish to thank Dr G. Choubert for giving information on the growth of different tissues of diploids and triploids of the same batches, J. Breque and P. Peyrotte for their technical assistance.

\section{REFERENCES}

Adibi S. A., Peterson J. A. and Krzysir B. A. (1975) Modulation of leucine transaminase activity by dietary means. Am. J. Physiol. 228, $432-435$.

Attaix D., Manghebati A., Grizard J. and Arnal M. (1987) Lack of effect of ${ }^{3} \mathrm{H}$-valine flooding dose on in vivo protein synthesis in lamb tissues. Biochim. biophys. Acta (In press)

Bacchus R. A. and London D. R. (1971) The measurement of arginine in plasma. Clinica Chim. Acta 33, 479-482.

Benfey T. J. and Sutterlin A. M. (1984) Oxygen utilization by triploid landlocked Atlantic salmon (Salmo salar L.). Aquaculture 42, 69-73.

Bohemen C. G. van, Lambert J. G. D. and Peute J. 1981 , Annual changes in plasma and liver in relation to vitellogenesis in the female rainbow trout, Salmo gairdnerii. Gen. comp. Endocr. 44, 94-107.

Bohemen C. G, van, Lambert J. G. D., Goos H. J. T. and Oordt P. G. N. G. van (1982) Estrone and oestradiol participation during exogenous vitellogenesis in the female rainbow trout, Salmo gairdneri. Gen. comp. Endocr. 46, 81-92.

Burton K. (1956) A study of the conditions and mechanism of the diphenylamine reaction for the colorimetric estimation of deoxyribonucleic acid. Biochem. J. 62 , 315-323.

Chevassus B. (1986) Caractéristiques et performances des lignées uniparentales et des polyploides chez les poissons d'eau froide. Proceedings of the 14 th Congress EIFAC/FAO on selection, hybridization and genetics engineering in aquaculture of fish and shellfish for consumption and stocking. Bordeaux, May, 1986.

Choubert G. and Blanc J. M. (1985) Flesh colour of diploid and triploid rainbow trout (Salmo gairdneri Rich.) fed canthaxanthine. Aquaculture 47, 299-304.

Chourrout D. (1980) Thermal induction of diploid gynogenesis and triploidy in the eggs of the rainbow trout (Salmo gairdneri Richardson). Reprod. Nutr. Devel. 20, 727-733.

Fauconneau B., Arnal M. and Luquet P. (1981) In vivo protein synthesis in the muscle of rainbow trout (Salmo gairdneri R.). Influence of temperature. Reprod. Nutr. Devel. 21, 293-301.

Fauconneau B. (1985) Protein synthesis and protein deposition in fish. In Fish Feeding and Nutrition (Edited by Cowey C. B., MacKie I. A. and Bell J. G.), pp 169-176. Academic Press, New York. 
Fauconneau B. and Arnal M. (1985) In vivo protein synthesis in different tissues of the whole body of rainbow trout (Salmo gairdneri R.). Influence of environmental temperature. Comp. Biochem. Physiol. 82A, 179-187.

Fauconneau B., Aguirre P., Dabrowski K. and Kaushik S. K. (1986a) Rearing of sturgeon (Acipenser baeri Brandt) larvae. 2-Protein metabolism: influence of fasting and diet quality. Aquaculture 51, 117-131.

Fauconneau B., Kaushik S. J. and Blanc J. M. (1986b) Utilisation de différents substrats energétiques chez la truite arc en ciel (Salmo gairdneri R.). Diabet Métab. 12, $111-112$.

Garlick P. J., MacNurlan M. A. and Preedy V. R. (1980) A rapid and convenient technique for measuring the rate of protein synthesis in tissues by injection of ${ }^{3} \mathrm{H}$-phenylalanine. Biochem. J. 192, 719-723.

Gras J., Gudefin Y. and Chagny F. (1978) Free amino acids and ninhydrine-positive substances in fish. 1. Muscle and skin of the rainbow trout (Salmo gairdneri Richardson). Comp. Biochem. Physiol. 60B, 368-372.

Habibi H. R. and Ince B. W. (1983) Effects of steroids and sex reversal on intestinal absorption of $\left.{ }^{14} \mathrm{C}\right]$-leucine in vivo in rainbow truut Salmo gairdneri. Gen. comp. Endocr. 52, 438-444.

Haschemeyer A. E. V. (1983) A comparative study of protein synthesis in nototheniids and iccfish at Palmer Station, Antarctica. Comp. Biochem. Physiol. 76B, $541-543$.

Haux C. and Norberg B. (1985) The influence of oestradiol $17-\beta$ on the liver content of protein, lipids, glycogen and nucleic acids in juvenile rainbow trout, Salmo gairdneri. Comp. Biochem. Physiol. 81B, 275-279.

Herbert D., Phipps P. J. and Strange R. E. (1971) Determination of nucleic acids. In Methods in Microbiology (Edited by Norris and Ribbons), Vol. SB, pp, 308-328, London.

Houlihan D. F., McMillan D. N. and Laurent P. (1986) Growth rates, protein synthesis, and protein degradation rates in rainbow trout: effect of body size. Physiol. Zool. 59, 482-493.

Johnston R. (1985) Induction of triploidy in Atlantic salmon by heat shock. Aquaculture 49, 133-139.

Lincoln R. F. and Scott A. P. (1984) Sexual maturation in triploid rainbow trout, Salmo gairdneri Richardson. J. Fish. Biol. 25, 385-392.

Loughna P. T. and Goldspink G. (1984) The effects of starvation upon protein turnover in red and white myotomal muscle of rainbow trout Salmo gairdneri Richardson. J. Fish. Biol. 25, 223-230.

Loughna P. T. and Goldspink G. (1985) Muscle protein synthesis during temperature acclimation in a eurythermal (Cyprinus carpio) and a stenothermal (Salmo gairdneri) species of teleost. J. exp. Biol. 118, 267-276.

Luquet P. (1971) Etude du développement chez la truite. Evolution de la teneur en acides nucléiques dans diverses fractions corporelles. Annls Biol. anim. Biochim. Biophys. 11, 657-668.

Luquet P. and Durand G. (1970) Evolution de la teneur en acide nucléiques de la musculature épaxiale au cours de la croissance chez la truite arc en ciel (Salmo gairdneri). Rôles respectifs de la multiplication et du grandissement cellulaire. Annis Biol. anim. Biochim. Biophys. 10, $481-492$.

Luquet P. and Watanabe T. (1986) Interaction "nutritionreproduction" in fish. Fish Physiol. Biochem. 2, 121-129.

Maitre J. L., Mercier L., Dolo L. and Valotaire Y. (1985) Caractérisation de récepteurs spécifiques à l'oestradiol; induction de la vitellogenine et de son mRNA dans le foie de truite arc en ciel (Salmo gairdneri). Biochimie 67, 215-225.

Medale F., Parent J. P. and Vellas F. (1987) Responses to prolonged hypoxia by rainbow trout (Salmo gairdneri). I Free amino acids and proteins in plasma, liver and white muscle. Fish Physiol. Biochem. (In press).

Munro H. N. and Fleck A. (1966) Recent developments in the measurement of nucleic acids in biological materials. A supplementary review. The Analyst 91, 78-88.

Oliva-Teles A. and Kaushik S. J. (1987) Nitrogen and energy metabolism during the early ontogeny of diploid and triploid rainbow trout (Salmo gairdneri R.). Comp. Biochem. Physiol. 88A, 45-48.

Philips A. J. (1972) Caloric and energy requirements. In Fish Nutrition (Edited by Halver J. E.) pp. 1-28. Academic Press, New York.

Pocrnjic, Z., Mathews R. W, Rappaport S. and Haschemeyer A. E. V. (1983) Quantitative protein synthetic rates in various tissues of a temperate fish in vivo by the method of phenylaianine swamping. Comp. Biochem. Physiol. 74B, 735-738.

Rumsey G. L. (1981) Significance of nitrogen metabolism: why does the salmonid require a high protein diet? Salmonid 5, 20-24.

Sakaguchi S. (1951) A new method for the colorimetric determination of arginine. J. Biochem., Jap. 37, 231-236.

Schmidt G. and Thannhauser S. J. (1945) A method for the determination of deoxyribonucleic acid, ribonucleic acid and phosphoproteins in animal tissues. J. biol. Chem. 161, 83-89.

Shulman G. E. (1974) Life Cycles in Fish. 258 pp. John Wiley \& Sons, New York.

Smith M. A. K. (1981) Estimation of growth potential by measurement of tissue protein synthetic rates in feeding and fasting rainbow trout, Salmo gairdneri Richardson. J. Fish. Biol. 19, 213-220.

Snedecor G. W. and Cochran W. C. (1971) Méthodes Statistiques. Gème édn. $649 \mathrm{pp}$. Ass. Coord. Techn. Agric. Paris.

Solar I. I., Donaldson E. M. and Hunter G. A. (1984) Induction of triploidy in rainbow trout (Salmo gairdneri Richardson) by heat shock, and investigation of early growth. Aquaculture 42, 57-67.

Tveranger B. (1985) Variation in growth rate, liver weight and body composition at first sexual maturity in rainbow trout. Aquaculture 49, 89-99.

Watanabe T., Takeuchi T., Saito M. and Nishimura K. (1984a) Effect of low protein-high calorie or essential fatty acid deficiency diet on reproduction of rainbow trout. Bull. Jap. Soc. scient. Fish. 50, 1207-1215.

Watanabe T., Itoh A., Murakami A., Tsukashima Y., Kitajima C. and Fujita S. (1984b) Effect of nutritional quality of diets given to broodstock on the verge of spawning on reproduction of red sea bream. Bull. Jap. Soc. scient. Fish. 50, 1023-1028.

Waterlow, J. C., Garlick P. J. and Millward D. J. (1978) Protein Turnover in Mammalian Tissues and in the Whole Body. Elsevier/North Holland Biomedical, Amsterdam.

Weatherley A. H. and Gill H. S. (1983a) Relative growth of tissues at different somatic growth rates in rainbow trout Salmo gairdneri Richardson. J. Fish. Biol. 22, 43-60.

Weatherley A. H. and Gill H. S. (1983b) Protein, lipid, water and caloric contents of immature rainbow trout Salmo gairdneri Richardson growing at different rates. J. Fish. Biol. 23, 653-673.

Wu C. (1959) A method for the determination of guanidinoacetic acid and arginine in biological fluids. Archs Biochem. Biophys. 85, 461-470.

Young V. R., Meredith C., Hoerr R., Bier D. M. and Matthews D. E. (1985) Amino acid kinetics in relation to protein and amino acid requirements: the primary importance of amino acid oxidation. In Substrate and Energy Metabolism in Man (Edited by Garrow J. S. and Halliday D.), pp. 119-134. J. Libbey, London. 